\title{
Comparative geochemistry of Archaean orthogneisses from the north-western quadrant of the Isukasia map sheet region, southern West Greenland
}

\author{
R. P. Hall
}

The Archaean gneiss complex of the north-western part of the 1:100 000 scale Isukasia map sheet region comprises predominantly of high-grade basic, intermediate and acid metaigneous gneisses. Relict intrusive relationships clearly indicate the relative ages of most of the composite magmatic episodes. However, some relationships are not obvious and a geochemical reconnaissance has been made in an attempt to elucidate whether or nor any of the various units are genetically related. Since it is the preserved igneous geochemical affinities which are under investigation, the prefix 'meta' which should be applied to all of the lithologies is omitted.

\section{Stratigraphic problems}

The field relationships and stratigraphy of the area are described by Hall \& Hughes (1982) and Garde et al. (1983) and reference should be made to the maps presented by these authors for details of the distribution of the lithologies discussed in this report. The oldest recognised rocks in the north-western area form a suite of gabbroic and metavolcanic pyroxene-bearing amphibolites, which locally include deformed pillow-structured units and which broadly correspond to the Malene gabbroic and metavolcanic units of the Godthåbsfjord region (McGregor, 1973; Hall, 1980a). These basic rocks were deformed and metamorphosed prior to their variable disruption during the injection of large bodies of diorite and tonalite, which were themselves fragmented by the intrusive precursors of the predominant leucocratic, trondhjemitic and granodioritic gneisses and granitic pegmatite. These combined dioritic to granitic rocks are believed to be equivalent to different generations of Nûk gneisses. The leucocratic gneisses are cut by thin dykes of pale grey gneiss and bodies of norite in the north and west of the area. The very large Taserssuaq tonalite body occupies the centre of the Isukasia map sheet region and forms the eastern boundary of the area under consideration.

Some stratigraphic problems which persist concern the possible genetic relationships between the Taserssuaq tonalites, the central diorite complex, the agmatised tonalitic rocks in the south of the area (referred to as 'southern tonalites') and the grey gneiss dykes within the leucocratic gneisses and the distinction between homogeneous, granulite facies noritic, gabbroic and dioritic rocks.

\section{Comparative geochemistry}

A full geochemical acount of all of the lithostratigraphic units is beyond the scope of this report. Analyses of two representative samples of each of the units in question are presented in Table 1 and a selection of major and trace elements are plotted against silica in fig. 17 . The variation in $\mathrm{Al}, \mathrm{Na}, \mathrm{P}, \mathrm{Sr}, \mathrm{Y}$ and $\mathrm{Zr}$ is greater within than between the units and thus, these 
Table 1. Representative analyses of rocks from the north-western part of the Isukasia map sheet area

\begin{tabular}{|c|c|c|c|c|c|c|c|c|c|c|c|c|}
\hline \multirow[b]{2}{*}{ wt $\%$} & \multicolumn{2}{|c|}{ Dior1tes } & \multicolumn{2}{|c|}{$\begin{array}{l}\text { Southern } \\
\text { Tonalites }\end{array}$} & \multicolumn{2}{|c|}{$\begin{array}{l}\text { Taserssuaq } \\
\text { Tonalites }\end{array}$} & \multicolumn{2}{|c|}{$\begin{array}{l}\text { Grey Gneles } \\
\text { Dykes }\end{array}$} & \multicolumn{2}{|c|}{$\begin{array}{l}\text { Leucocratic } \\
\text { Gne1sses }\end{array}$} & \multicolumn{2}{|c|}{ Norites } \\
\hline & 220556 & 220581 & 220573 & 220569 & 290544 & 290549 & 290590 & 290580 & 220561 & 290522 & 220525 & 220550 \\
\hline $\mathrm{S}_{2} \mathrm{O}_{2}$ & 52.89 & 53.75 & 56.61 & 61.15 & 57.70 & 59.14 & 56.46 & 62.94 & 67.24 & 69.39 & 51.80 & 52.50 \\
\hline $\mathrm{Al}_{2} \mathrm{O}_{3}$ & 18.42 & 19.05 & 17.47 & 16.44 & 19.12 & 18.05 & 17.03 & 17.26 & 16.75 & 15.40 & 17.76 & 17.60 \\
\hline $\mathrm{M}$ EO & 6.35 & 3.29 & 2.86 & 2.42 & 2.79 & 2.45 & 3.19 & 1.46 & 1.04 & 0.52 & 6.26 & 5.88 \\
\hline $\mathrm{Fe}_{2} \mathrm{O}_{3}$ & 5.64 & 7.74 & 7.32 & 5.90 & 6.23 & 5.84 & 8.55 & 4.37 & 3.11 & 1.91 & 7.97 & 7.61 \\
\hline $\mathrm{CaO}$ & 8.77 & 7.25 & 6.35 & 5.50 & 6.29 & 5.50 & 6.16 & 4.00 & 3.14 & 1.70 & 8.98 & 8.35 \\
\hline $\mathrm{Na}_{2} \mathrm{O}$ & 3.12 & 3.68 & 4.91 & 4.93 & 4.48 & 4.44 & 4.13 & 5.21 & 5.12 & 4.51 & 4.20 & 4.04 \\
\hline $\mathrm{K}_{2} \mathrm{O}$ & 0.56 & 1.23 & 0.99 & 0.99 & 1.20 & 1.38 & 1.73 & 1.65 & 2.44 & 3.73 & 0.32 & 0.28 \\
\hline $\mathrm{THO}_{2}$ & 0.19 & 0.80 & 0.84 & 0.68 & 0.70 & 0.68 & 1.29 & $0.6 ?$ & 0.43 & 0.29 & 0.73 & 0.75 \\
\hline $\mathrm{MnO}$ & 0.09 & 0.08 & 0.12 & 0.08 & 0.08 & 0.08 & 0.11 & 0.04 & 0.03 & 0.02 & 0.12 & 0.11 \\
\hline $\mathrm{P}_{2} \mathrm{O}_{5}$ & 0.04 & 0.32 & 0.35 & 0.21 & 0.18 & 0.16 & 0.50 & 0.19 & 0.14 & 0.10 & 0.23 & 0.25 \\
\hline Total & $\overline{96.07}$ & $\overline{97.19}$ & 97.82 & 98.30 & $\overline{98.77}$ & 97.72 & 99.15 & $\overline{97.79}$ & $\overline{98.44}$ & $\overline{97.57}$ & 98.37 & 97.37 \\
\hline \multicolumn{13}{|l|}{ ppm } \\
\hline $\mathrm{Sc}$ & 17 & 17 & 15 & 12 & 16 & 17 & 18 & $?$ & 7 & 4 & 21 & 25 \\
\hline $\mathrm{Ni}$ & 142 & 48 & 23 & 17 & 23 & 21 & 42 & 9 & n.a. & n.a. & 157 & 154 \\
\hline $\mathrm{Rb}$ & 3 & 36 & 6 & $?$ & 20 & 24 & 36 & 54 & 14 & 45 & n.d. & n.d. \\
\hline $\mathrm{Sr}$ & 620 & 670 & 486 & $4^{\prime}+2$ & 666 & 564 & 407 & 367 & 695 & 540 & 650 & 631 \\
\hline$Y$ & 3 & 10 & 14 & 8 & 14 & 12 & 24 & 5 & 2 & 1 & 8 & 15 \\
\hline $\mathrm{Zr}$ & 15 & 63 & 203 & 146 & 100 & 157 & 254 & 297 & 191 & 172 & 85 & 89 \\
\hline
\end{tabular}

All Fe expressed as $\mathrm{Fe}_{2} \mathrm{O}_{3}$, n.a.: not analysed; n.d.: not detectable.

elements have not proved very useful in distinguishing different lithologies. The most immediately recognised feature on the variation diagrams is the wide geochemical spread of many of the units. No unit is geochemically discrete from the others, but neither are any two units completely coincident.

The early dioritic rocks from the central part of the area are distinguished from the coarser, more quartz-rich southern tonalites. The latter tend to have higher $\mathrm{Si}, \mathrm{K}$ and $\mathrm{Rb}$ and lower $\mathrm{Mg}, \mathrm{Fe}, \mathrm{Ca}, \mathrm{Sc}$ and $\mathrm{Ni}$ contents. These two suites are thought to represent separate but penecontemporaneous early-Nûk intrusions. The central 'diorites' are in fact highly variable and range in composition from gabbroic to tonalitic types. The more basic members are almost indistinguishable from bodies of so-called 'norite' (Nielsen, 1976; Secher, 1983). In the field it is sometimes difficult to assign bodies of homogeneous, massive, mafic granulite facies rock to a gabbroic, noritic or dioritic origin, where all three rock types are known to occur. Basic rocks associated with the Malene supracrustal suite and the Ameralik dykes can be distinguished by their tholeiitic chemical affinities (Hall, 1980a, 1982; Chadwick, 1981), whereas all the units in the present study define a clear calc-alkali trend (fig. 18). The 'norites' have been reported to be Ni-rich (Nielsen, 1976), but the five

Fig. 17. Plot of selected major element oxides (wt \%), trace elements (ppm) and $\mathrm{MgO} /\left(\mathrm{MgO}+\mathrm{FeO}^{*}\right.$ ) against $\mathrm{SiO}_{2}$ (wt \%) where $\mathrm{FeO}^{*}$ is all iron expressed as $\mathrm{FeO}$. Diamonds: norites; dots: diorites; open circles: southern tonalites; filled asterisks: Taserssuaq tonalites; open asterisks: grey gneiss dykes; squares: trondhjemitic gneisses. No $\mathrm{Ni}$ data are available for the trondhjemitic gneisses. 


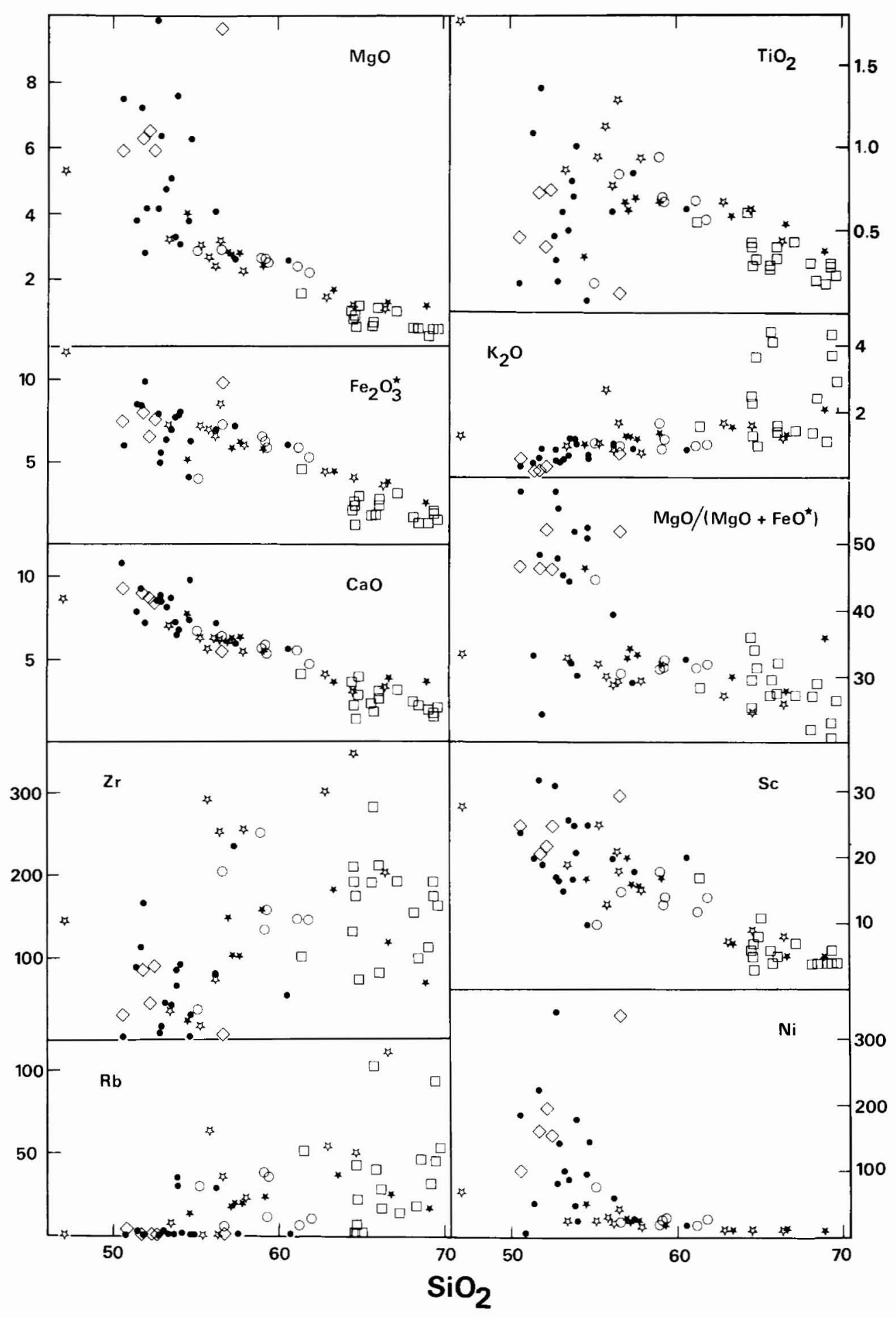




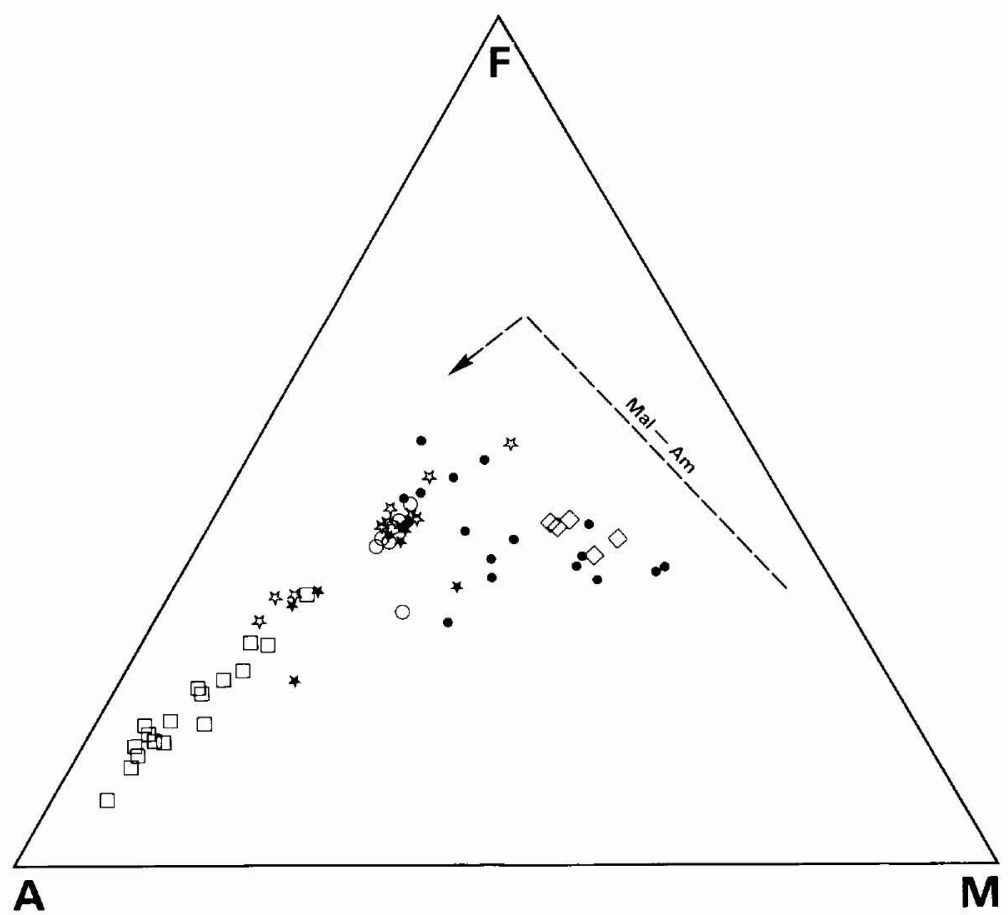

Fig. 18. Calc-alkali trend defined on an AFM plot $\left(\left(\mathrm{Na}_{2} \mathrm{O}+\mathrm{K}_{2} \mathrm{O}\right):\left(\mathrm{FeO}^{*}+\mathrm{MnO}\right): \mathrm{MgO}\right)$ of the various lithostratigraphic units in the north-western part of the Isukasia map sheet area. The tholeiitic trend of Malene metavolcanic and gabbroic units and Ameralik dykes (Mal-Am) is drawn schematically for comparison (see Chadwick, 1981; Hall, 1982). Symbols as for fig. 17.

analysed samples have only the same moderate Ni values $(100-400 \mathrm{ppm})$ as the more basic members of the central diorite suite, which are lower than in the Malene komatiitic amphibolites (up to $1200 \mathrm{ppm}$ ) from Ivisârtoq (Hall, 1980a).

Occasionally the 'norites' contain abundant mixed inclusions of amphibolite and leucocratic gneiss (fig. 19). These and similar rocks with an apparently ultramafic matrix (Hall \& Hughes, 1982) may be related to the 'ultrabasic pipe' found further to the north on the nunatak Majorqap alángua (Hall, 1980b). The diorite and norite suites are probably of different ages, separated by the formation of the leucocratic gneisses, although it is possible that the leucocratic fragments within the 'norite' represent older acid material pre-dating a single early-Nûk norite/gabbro/diorite intrusion.

The Taserssuaq tonalite is a variable but clearly more chemically evolved unit than the early central diorite complex (fig. 18). Rare earth element (REE) distribution patterns are similar in these two suites, both having moderately light REE-enriched profiles (fig. 20). The REE values tend to be a little higher in the more evolved Taserssuaq tonalites (Table 2), but the ranges in chondrite-normalised REE fractionation index $\mathrm{Ce}_{\mathrm{N}} / \mathrm{Yb}_{\mathrm{N}}$ are the same for both suites $\left(\mathrm{Ce}_{\mathrm{N}} / \mathrm{Yb}_{\mathrm{N}}=5.8-20.1\right.$ and 8.7-25.7 in the diorites and Taserssuaq rocks respectively) and are similar to those of the early Nûk diorites and tonalites of the Buksefjorden 


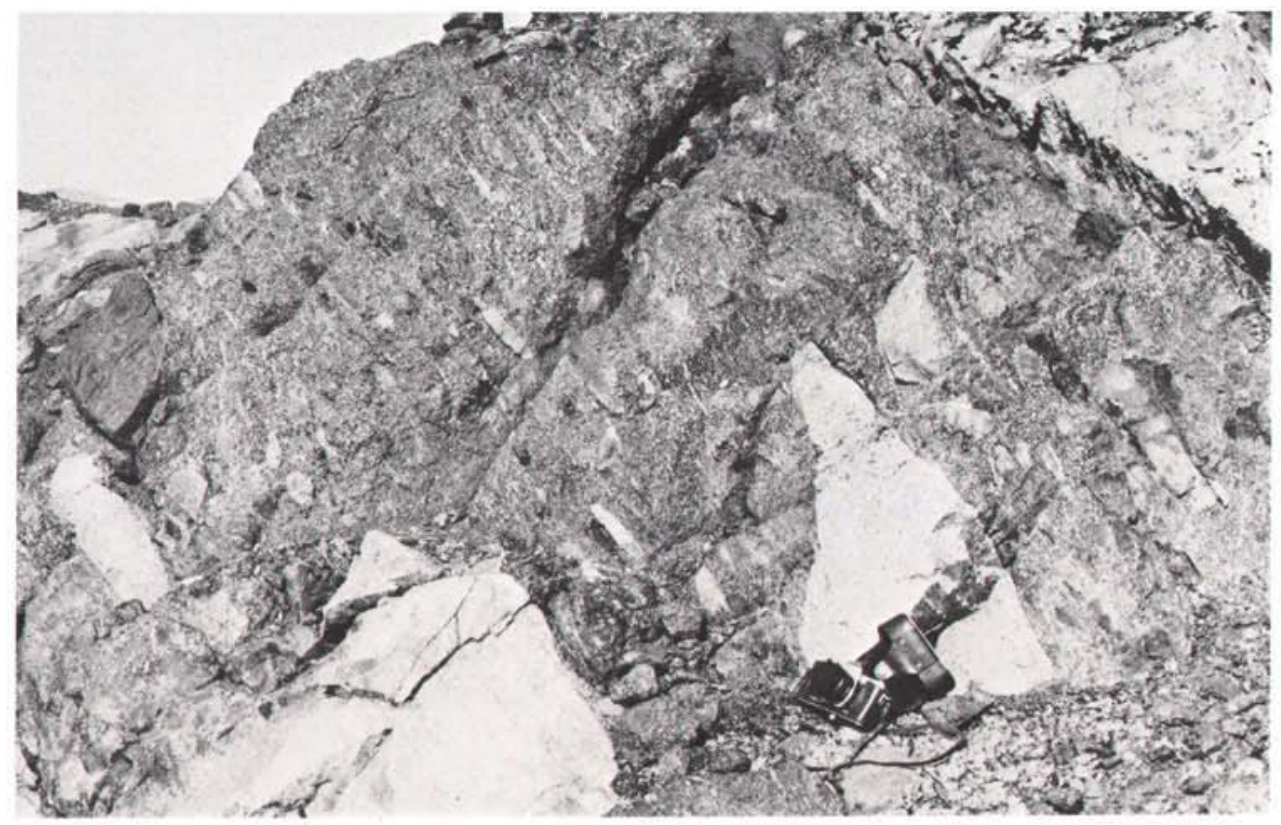

Fig. 19. Deformed intrusion breccia comprised of a mixture of pyroxene-amphibolitic and leucocratic gneiss xenoliths within a metanorite matrix in the north-western corner of the Isukasia map sheet area. Similar structures have been found within the early diorites (Hall \& Hughes, 1982) and in rocks with an ultramafic matrix (Hall, 1980b; Hall \& Hughes, 1982).

region (Compton, 1978). The differences in geochemistry between the diorites and Taserssuaq tonalites may reflect different stages of fractional crystallisation of similar parent magmas or different degrees of partial melting of the same amphibolitic(?) source (cf. Arth \& Hanson, 1972). There is no petrographic evidence of feldspar accumulation to account for the slight positive Eu anomaly in the Taserssuaq tonalite samples 290545 and 277441.

The grey gneiss dykes vary from basic members $\left(\mathrm{SiO}_{2}=47 \mathrm{wt} \%\right)$ which correspond to 'intra-Nuk amphibolite dykes' from elsewhere in the region (cf. Coe, 1980; Coe \& Robertson, 1982; Chadwick, 1981; Hall 1981) to intermediate and acid varieties of which similar late-stage dykes have also been reported from other areas (Bridgwater et al., 1976; Hall, 1977). These dykes do not seem to form a geochemically coherent suite and whether they are all genetically related remains unclear. As a whole they tend to have slightly lower $\mathrm{Mg}$ and $\mathrm{Ca}$ and higher $\mathrm{Fe}, \mathrm{Ti}, \mathrm{Zr}$ and $\mathrm{Rb}$ values compared to Taserssuaq tonalites of equivalent silica content. This chemical discrepancy precludes the possibility that the grey dykes represent marginal emanations of the large Taserssuaq tonalite body.

The predominant leucocratic gneisses vary from tonalitic to granodioritic members, although most are trondhjemitic having low alkali feldspar and $\mathrm{K}_{2} \mathrm{O}$ contents (cf. Barker, 1979). They are the most silica-rich rocks in the area and have relatively high $\mathrm{Rb}$ and $\mathrm{K}$ and low $\mathrm{Mg}, \mathrm{Fe}, \mathrm{Ca}, \mathrm{Mn}$, and $\mathrm{Sc}$ contents. $\mathrm{K} / \mathrm{Rb}$ and $\mathrm{Rb} / \mathrm{Sr}$ ratios (fig. 21 ) tend to support the 


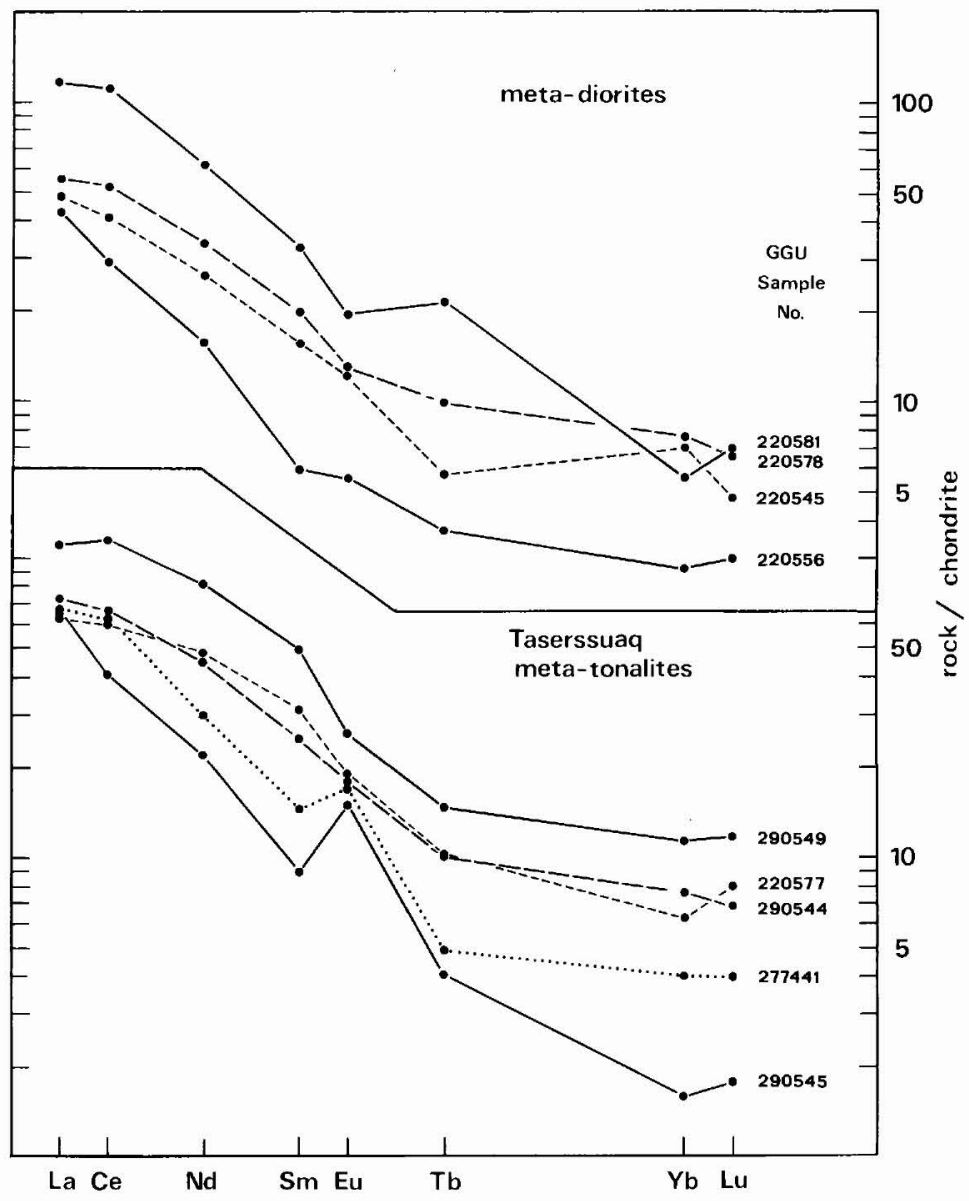

Fig. 20. Chondrite-normalized REE distribution patterns in four metadiorite and five Taserssuaq metatonalite samples. The average chondrite values are taken from Nakamura (1974) with an interpolated $\mathrm{Tb}$ value of $0.05 \mathrm{ppm}$.

hypothesis that some of the late-stage leucocratic gneisses and the grey gneiss dykes were intruded during the post-granulite facies retrograde metamorphism (Hall \& Hughes, 1982). Granulite facies rocks are known to have higher $\mathrm{K} / \mathrm{Rb}$ and lower $\mathrm{Rb} / \mathrm{Sr}$ ratios than their amphibolite facies equivalents (e.g. Tarney \& Windley, 1977; Wells, 1979). Some of the gneisses and dykes show no petrographic evidence of retrogression from granulite facies and have $\mathrm{K} / \mathrm{Rb}$ values less than 500 and $\mathrm{Rb} / \mathrm{Sr}$ greater than 0.05 , suggesting that they have only attained amphibolite grade. However, as these chemical ratios are best used for discriminating granulite and amphibolite grade gneisses of similar bulk compositions, the comparison of, for example, the granulite facies diorites with possibly amphibolite facies trondhjemites and granodiorites is only partially successful. Although the Taserssuaq tonalites also only in rare instances show petrographic indication of their having been retrogressed from granulite 
Table 2. Neutron activation rare earth element analyses

\begin{tabular}{|c|c|c|c|c|c|c|c|c|c|}
\hline $\begin{array}{l}\text { Diorites } \\
\text { GGU Sample }\end{array}$ & La & $\mathrm{Ce}$ & $\mathrm{Nd}$ & $\mathrm{Sm}$ & $\mathrm{Eu}$ & $\mathrm{Tb}$ & $\mathrm{Yb}$ & $\mathrm{Lu}$ & $\mathrm{Ce}_{\mathrm{N}} / \mathrm{Yb}_{\mathrm{N}}$ \\
\hline 220545 & 15.92 & 35.79 & 16.80 & 3.19 & 0.96 & 0.30 & 1.57 & 0.16 & 5.8 \\
\hline 220556 & 14.18 & 25.44 & 9.86 & 1.24 & 0.43 & 0.19 & 0.62 & 0.10 & 10.4 \\
\hline 220578 & 18.37 & 45.51 & 21.31 & 4.01 & 0.99 & 0.51 & 1.70 & 0.23 & 6.8 \\
\hline 220581 & 39.24 & 97.43 & 39.19 & 6.59 & 1.50 & 1.14 & 1.23 & 0.24 & 20.1 \\
\hline \multicolumn{10}{|l|}{$\begin{array}{l}\text { Taserssuaq } \\
\text { Tonalites }\end{array}$} \\
\hline 290544 & $24 \cdot 12$ & 58.00 & 28.83 & 5.13 & 2.41 & 0.53 & 1.70 & 0.24 & 8.7 \\
\hline 290545 & 22.12 & 35.34 & 23.63 & 1.82 & 1.16 & 0.21 & 0.35 & 0.06 & 25.7 \\
\hline 290549 & 36.34 & 99.21 & 51.72 & 9.88 & 2.01 & 0.77 & 2.52 & 0.40 & 10.0 \\
\hline 220577 & 20.94 & 52.78 & 30.18 & 6.36 & 1.45 & 0.51 & 1.40 & 0.27 & 9.6 \\
\hline 277441 & 21.25 & 53.92 & 18.86 & 2.96 & 1.31 & 0.26 & 0.89 & 0.14 & 15.5 \\
\hline
\end{tabular}
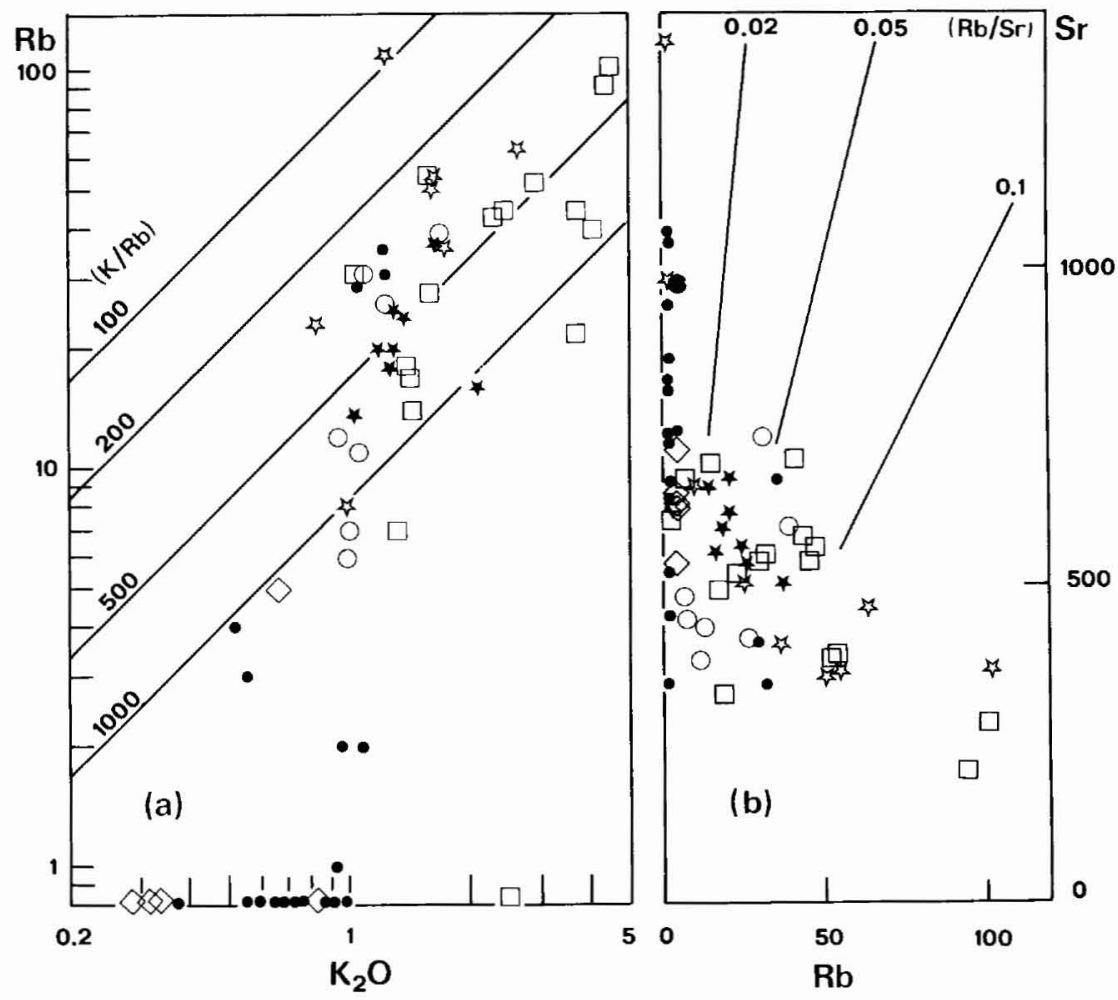

Fig. 21. (a) Contoured $\mathrm{Rb}(\mathrm{ppm})-\mathrm{K}_{2} \mathrm{O}$ (wt \%) and (b) $\mathrm{Sr}-\mathrm{Rb}$ (ppm) variation diagrams. Symbols as for fig. 17. 
facies (Garde et al., 1983), the analysed Taserssuaq samples have relatively low $\mathrm{Rb} / \mathrm{Sr}$ (around 0.03 ) and slightly high $\mathrm{K} / \mathrm{Rb}$ ratios (fig. 21).

\section{Conclusions}

Problems in attempting to correlate or distinguish certain lithological units in the northwestern part of the Isukasia region have been partially resolved by the geochemical differences between them. It appears that the various basic, intermediate and acid orthogneisses identified in the field represent discrete lithostratigraphic units and originally separate magmatic events. They comprise a complex which is equated with the Nûk gneiss complex of the Godthåbsfjord region. Difficulties remain in distinguishing disrupted bodies of homogeneous 'norite' and 'diorite' where no primary igneous features are preserved.

Acknowledgements. D. J. Hughes supplied some of the analysed samples and data and is thanked for discussion, both in the field and in Portsmouth. The neutron activation REE analyses were kindly provided by R. Oliver, at the I.L.L. Reactor Centre and Institute of Geology, University of Grenoble.

\section{References}

Arth, J. G. \& Hanson, G. N. 1972: Quartz diorites derived by partial melting of eclogite or amphibolite at mantle depths. Contrib. Mineral. Petrol. 37, 161-174.

Barker, F. 1979: Trondhjemite: definition, environment and hypotheses of origin. In Barker, F. (edit.), Trondhjemites, dacites and related rocks, 1-12. Amsterdam: Elsevier.

Bridgwater, D., Keto, L., McGregor, V. R. \& Myers, J. S. 1976: Archaean gneiss complex of Greenland. In Escher, A. \& Watt, W. S. (edit.) Geology of Greenland, 18-75. Copenhagen: Geol. Surv. Greenland.

Chadwick, B. 1981: Field relations, petrography and geochemistry of Archaean amphibolite dykes and Malene supracrustal amphibolites, northwest Buksefjorden, southern West Greenland. Precambrian Res. 14, 221-259.

Coe, K. 1980: Nûk gneisses of the Buksefjorden region, southern West Greenland, and their enclaves. Precambrian Res.11, 357-371.

Coe, K. \& Robertson, S. 1982: Mapping of Archaean rocks in part of the Ivisârtoq sheet. Rapp. Grønlands geol. Unders. 110, 63-67.

Compton, P. 1978: Rare earth evidence for the origin of the Nûk gneisses Buksefjorden region, southern West Greenland. Contrib. Mineral. Petrol. 66, 283-293.

Garde, A. A., Hall, R. P., Hughes, D. J., Jensen, S. B., Nutman, A. P. \& Stecher, O. 1983: Mapping of the Isukasia sheet, southern West Greenland. Rapp. Grønlands geol. Unders. 115, 20-29.

Hall, R. P. 1977: The Precambrian geology of the Kangangup tasia area, Fiskenaesset, southern West Greenland. Unpubl. M. Phil. thesis, Council for National Academic Awards, Portsmouth Polytechnic.

Hall, R. P. 1980a: The tholeiitic and komatiitic affinities of the Malene metavolcanic amphibolites from Ivisârtoq, southern West Greenland. Rapp. Grønlands geol. Unders. 97, 20 pp.

Hall, R. P. 1980b: An ultrabasic pipe in the eastern Sukkertoppen region, southern West Greenland. Rapp. Grønlands geol. Unders. 100, 69-73.

Hall, R. P. 1981: The Archaean geology of Ivisârtoq, inner Godthåbsfjord, southern West Greenland, Unpubl. Ph. D. thesis, Council for National Academic Awards, Portsmouth Polytechnic.

Hall, R. P. 1982: Geochemistry of the Malene metavolcanic amphibolites from Ivisârtoq: significance to the Archaean stratigraphy of southern West Greenland. Rapp. Grønlands geol. Unders. 110, 68-72. 
Hall, R. P. \& Hughes, D. J. 1982: Transitional amphibolite-granulite facies granites, diorites and metavolcanic amphibolites in the Isukasia map sheet, southern West Greenland. Rapp. Grønlands geol. Unders. 110, 46-49.

McGregor, V. R. 1973: The early Precambrian gneisses of the Godthåb district, West Greenland. Phil. Trans. R. Soc. Lond. A 273, 343-358.

Nakamura, N. 1974: Determination of REE, Ba, Fe, Mg, $\mathrm{Na}$ and $\mathrm{K}$ in carbonaceous and ordinary chondrites. Geochim. cosmochim. Acta 38, 757-775.

Nielsen, B. L. 1976: Economic minerals. In Escher, A. \& Watt, W. S. (edit.) Geology of Greenland, 460 487. Copenhagen: Geol. Surv. Greenland.

Secher, K. 1983: Noritic rocks and associated nickel-copper-sulphide occurrences in Sukkertoppen district, central West Greenland. Rapp. Grønlands geol. Unders. 115, 30-34.

Tarney, J. \& Windley, B. F. 1977: Chemistry, thermal gradients and evolution of the lower continental crust. J. geol. Soc. Lond. 134, 153-172.

Wells, P. R. A. 1979: Chemical and thermal evolution of Archaean sialic crust, southern West Greenland. J. Petrol. 20, 187-226.

Department of Geology,
Portsmouth Polytechnic,
Burnaby Road,
Portsmouth POI $3 Q L$,
U.K.

\title{
Field work between Fiskefjord and Godthåbsfjord, southern West Greenland
}

\begin{abstract}
Adam A. Garde
Introduction

The 1980-1981 field work in Precambrian basement rocks for the Fiskefjord map sheet was continued in 1983 . V. R. McGregor mapped granulite facies gneisses south of outer Fiskefjord in the south-western part of the map sheet area. The author worked inland between Godthåbsfjord and Fiskefjord from the eastern map sheet boundary at $50^{\circ} 54^{\prime} \mathrm{E}$ westwards to $51^{\circ} 45^{\prime} \mathrm{E}$ (fig. 22) and some notes concerning the lithologies, geometry and geochronology of this area are presented below.

The GGU cutter $K . J$. V. Steenstrup and a Jet Ranger helicopter on weekly charter from Godthåb provided logistic support for the two Fiskefjord teams and for four teams mapping in the Ivisârtoq area (see Brewer et al., this report) as well as for the GGU glaciological station at Qamanârssûp sermia.
\end{abstract}

\section{Lithologies and field relations}

The area mapped by the author (fig. 22) is underlain by uniform and homogeneous orthogneisses, equivalent to the Nûk gneisses of the Godthåbsfjord region, in which there 